\title{
WHY THE ARTS MATTER: AN AESTHETIC EXPLORATION OF INDIA'S CULTURAL DIVERSITY
}

\author{
Mahira Jain \\ Delhi Public School, R.K. Puram
}

DOI: 10.46609/IJSSER.2020.v05i05.015 URL:https://doi.org/10.46609/IJSSER.2020.v05i05.015

\begin{abstract}
Indian art and architecture has a rich history and diversity, reflected from ancient times, through various dynasties, through post-independence movements and contemporary art, and the architecture that now exists in a globalized and technologically integrated world. It is both interesting and important to pay attention to the arts, and its ever expanding domains, as art has been crucial to shaping national and cultural identities, as well as been the result of serious controversies. From an educational standpoint, it is important that art education be introduced at the earliest levels to foster critical thinking, which better enables citizenry to tackle complicated questions pertaining to censorship, morality, and the celebration of public memory. This paper will undertake an aesthetic exploration of Indian art and architecture, providing a brief history and reviewing its current trends. The paper will then pose recommendations and emphasize the important of arts in the educational sphere for the shaping of culture.
\end{abstract}

Keywords: Indian art, Architecture, Culture, Tradition, Cultural diversity

\section{INTRODUCTION}

Architecture is perhaps India's greatest glory. Among the most-renowned monuments are many cave temples hewn from rock (of which those at Ajanta and Ellora are most noteworthy); the Sun Temple at Konarak (Konarka); the vast temple complexes at Bhubaneshwar, Khajuraho, and Kanchipuram (Conjeeveram); such Mughal masterpieces as Humayun's tomb and the Taj Mahal; and, from the 20th century, buildings such as the High Court in the planned city of Chandigarh, designed by the Swiss-born architect Le Corbusier, and the Bhopal State Assembly building in Bhopal, Madhya Pradesh, designed by the Indian architect and urban planner Charles Correa (Dikshit and Schwartzberg, 2020; Harle, 1994). Also notable are stepwells, such as the Rani ki 


\section{International Journal of Social Science and Economic Research}

ISSN: $2455-8834$

Volume: 05, Issue: 05 "May 2020"

Vav (“Queen's Stepwell”) in Patan (northern Gujarat), now a UNESCO World Heritage site (Dikshit and Schwartzberg, 2020).

There is great diversity in the history of Indian art and architecture, starting with the early Harappan art and architecture, moving on to Mauryan art and architecture, and the various dynasties that existed in India such as the Mughals, Cholas, Pandyas, etc. Among a number of architectural styles and traditions, the contrasting Hindu temple architecture and Indo-Islamic architecture are the best known historical styles (Thapar, 2004; Harle, 1994). Both of these, but especially the former, have a number of regional styles within them. An early example of town planning was the Harappan architecture of the Indus Valley Civilisation (Thapar, 2004; Harle, 1994).

Dravidian architecture flourished during the rule of the Chola, Chera, and Pandyan empires, as well as the Vijayanagara Empire (Tagdell, 1990). The first major Islamic kingdom in India was the Delhi Sultanate, which led to the development of Indo-Islamic architecture, combining Indian and Islamic features (Tagdell, 1990). The rule of the Mughal Empire, when Mughal architecture evolved, is regarded as the zenith of Indo-Islamic architecture, with the Taj Mahal being the high point of their contribution (Tagdell, 1990). Indo-Islamic architecture influenced the Rajput and Sikh styles as well (Tagdell, 1990).

During the British colonial period, European styles including neoclassical, gothic revival, and baroque became prevalent across India. The amalgamation of Indo-Islamic and European styles led to a new style, known as the Indo-Saracenic style (Gast, 2007). The post independence period led to a time of modern and contemporary Indian art and architecture (Gast, 2007). Throughout India's history, art and architecture have changed depending on historical movements, and been a reflection on the time and public memory. Studying such art and architecture today is important, to examine India's evolution and critically comment on the nation's historical memory.

This paper will analyze how Indian art and architecture has evolved over time, and undertake a sociological study of how public art affects movements, and shapes culture and remembrance of history. The paper will then pose recommendations from an educational perspective to better incorporate a study of the arts and architecture into the Indian curriculum to foster life skills such as critical appreciation, empathy and historical understanding.

\section{BACKGROUND}

Art and architecture has reflected historical movements, such as the Aryan, Mughal, Modern and post independence period. A technologically advanced and sophisticated urban culture came 


\section{International Journal of Social Science and Economic Research}

ISSN: $2455-8834$

Volume: 05, Issue: 05 "May 2020"

about with the Harappan period, which was subsequently followed by The Bronze Age and later, The Iron Age Vedic Civilization (Camlin, 2013). Rock paintings and temple art can be traced back to the artistic expressions of ancient India. During Islamic rule, the imperial, provincial and mughal style of architecture flourished (Camlin, 2013). The defeat of Tipu Sultan led to rapid expansion of British power and by mid $19^{\text {th }}$ century British India was born under the governance of the British Empire (Camlin, 2013). During this time, the Bengal School of Art was formed. Also, a select group of artists introduced many avant garde western styles into Indian art (Camlin, 2013) The post colonial period saw the rise of many Indian artists who pushed artistic boundaries, resulting in what we call contemporary art today (Camlin, 2013). Artists like Jitish Kallat, Subodh Gupta, Nalini Malani and many others found radical new directions for their art work (Camlin, 2013).

The nationalist response to colonial prejudices translated as a quest for researching the origins, rationale, 'inner meaning,' and above all, the 'Indian-ness' of Indian art (Singh, 2018). The aesthetic appreciation of Indian art, beyond its usefulness as a visual document of Indian history, was also in evidence (Singh, 2018). To meet these objectives, methodological approaches came to be rooted at first in symbolism, iconography, and iconology (Singh, 2018). This in turn led to a concerted engagement with texts during the first half of the twentieth century (Singh, 2018). The search for meaning required an understanding of cultural contexts - myth, religion, literature, the language of gesture and posture, technical treatises, literary texts, and local culture (Singh, 2018). To the Western mind, this knowledge seemed more remote and difficult to cultivate than to apply the already evolved Western art historical methods to an interpretation of form and style (Singh, 2018).

The current state of public are shows how our cities carry history through art and monuments. The juxtaposition of ancient and contemporary art/architecture reveals our country's history of evolution through empires, wars, and is a reflection of changing times (Jadhav, in Gast, 2007). For example, in recent times there has been a movement of population from rural areas to urban centres of industry, leading to price rise in property in various cities of India (Jadhav, in Gast, 2007). Urban housing in India balances space constrictions and is aimed to serve the working class (Jadhav, in Gast 2007). Growing awareness of ecology has influenced architecture in India during modern times (Gast, 2007).

Climate responsive architecture has long been a feature of India's architecture but has been losing its significance as of late (Gast, 2007). Indian architecture reflects its various socio-cultural sensibilities which vary from region to region. Certain areas are traditionally held to be belonging to women (Gast, 2007). Villages in India have features such as courtyards, loggias, terraces and balconies (Gast, 2007). Calico, chintz, and palampore-of Indian origin-highlight the 


\section{International Journal of Social Science and Economic Research}

ISSN: $2455-8834$

Volume: 05, Issue: 05 "May 2020"

assimilation of Indian textiles in global interior design. Roshandans, which are skylights-cumventilators, are a common feature in Indian homes, especially in North India (Gast, 2007). Globalization has also led to the importation of architectural styles, such as sky scrapers, in the model of big cities in the United States.

Architects are joining in social movements and demanding public dialogues to curb the disconnect between what people want and what is being offered to them (Dutta, 2018). In terms of safety and security, architects are bringing into focus the 'gendering of spaces' and concepts such as 'eyes on the street' (Dutta, 2018). There has also been a surge of non-profit organizations in the country, who are not only voicing their opinions on the degradation of design and cities, but are physically working on solutions. Through this, citizens are able to participate in building their cities like never before (Dutta, 2018).

\section{DISCUSSION}

What is clear from the above background is that public art and architecture, and the transitions it goes through, serves as a marker of the time we live in - our shared attitudes, beliefs, values and culture. There are different indicators and structures that serve as markers of time. For example, Mohenjo-daro has wells which may be the predecessors of the stepwell (Milo, 2002). As many as 700 wells have been discovered in just one section of the city, leading scholars to believe that 'cylindrical brick lined wells' were invented by the Indus Valley Civilization. Structures such as arches suggest an Indo-Aryan influence (Milo, 2002). Structures that survive today such as the Buddhist stupas and the Ashoka columns show a Greek and Persian influence had entered India (Milo, 2002). The Gupta period left almost the first surviving free-standing structures in India, in particular, the beginnings of Hindu temple architecture (Milo, 2002). Huge structures that show Indo-Islamic influence and the reign of the Mughals continue to exist- such as the Qutb Minar complex, the tombs of Humayun and Akbar, the Red Fort, the Taj Mahal, and at Fatehpur Sikri, among several other examples (UNESCO, n.d). Till date, Mumbai, (then known as Bombay) has some of the most prominent examples of British colonial architecture (UNESCO, 2018). This included the gothic revival (Victoria terminus, University of Mumbai, Rajabai Clock Tower, High Court, BMC Building), Indo-Saracenic (Prince of Wales Museum, Gateway of India, Taj Mahal Palace Hotel) and art deco (Eros Cinema, New India Assurance Building) (UNESCO, 2018). The work of major Indian artists are also referred to as cultural artefacts. Works of Raja Ravi Verma, Amrita Shergill, SL Haldankar, among other several notable artists are remembered and preserved. Works of Indian art have also caused controversy as artists pushed boundaries, such as the work of MF Hussain. Hussain's work in particular has been regarded as controversial in many ways, forcing the artist into exile in 2006 until his death (Buncombe, 2011). 


\section{International Journal of Social Science and Economic Research}

ISSN: $2455-8834$

Volume: 05, Issue: 05 "May 2020"

Further, there continue to be controversies surrounding architecture, which brings into debate a national culture or national identity and conflicting ideas of the public. Possibly the most telling example of the effect that architecture can have on public memory is the demolition of the Babri Masjid and the recent Supreme Court judgment which allowed for the construction of the Ram Temple on that ground. The dispute saw several excavations, digging up structures to prove the existence of a Hindu temple. The issue had been greatly politicized by the right wing Hindu nationalists as a battle for the soul of India itself. Therefore, it is clear that both art and architecture are still a subject of great public debate and crucial for shaping the culture of the nation, both on an individual level and as a collective.

The digital world is, in a sense, working as a stimulus where culture can grow. It is allowing for pockets of communities to develop, acting not as an end point for culture but a means of discovery that audiences can then go out to experience, through making different types of expression freely available to a much broader audience (Agrawal, 2020). And in a circular feeding off each-other, it's the visibility of an audience that gives cultural professionals the impetus to create cultural spaces and experiences, resulting in a growing alternate culture scene (Agrawal, 2020). In blurring the divides between mainstream culture, alternative subcultures, and the grassroots counterculture, the internet is reducing the elitism that comes with consuming only one kind of content or being only interested in one kind of thing (Agrawal, 2020). Therefore, the boundaries of art itself are ever expanding and changing in India, in a manner that could never have been contemplated just a mere decade ago (Agrawal, 2020). The digital sphere is allowing for pockets of communities to develop, acting not as end point for art and culture, but a means of discovery that audiences can then go out and experience. It is moulding India's cultural sensibility in a decidedly democratic way (Agrawal, 2020).

\section{CONCLUSION}

What is clear from examining art and architecture through the ages, is that appreciating and thinking critically about the origins and reasons for cultural preservation is an important skill. Incorporating these studies at all levels of education and especially at the primary level fosters an understanding of the importance of history and cultural preservation at an early stage. Further, an appreciation of the arts can lead to better life skills, such as empathy, awareness, and critical thinking with appropriate context.

Art education needs to be approached in a more structured manner, looking at theory as well as context. Besides learning about the elements like line, shape, colour, space, texture and form, children must also learn art history (Kumar, 2018). It is important because, in essence, they are being introduced to innovators. Further, Indian schools need to take advantage of India's rich 


\section{International Journal of Social Science and Economic Research}

ISSN: $2455-8834$

Volume: 05, Issue: 05 "May 2020"

tradition of art and folk art (Kumar, 2018). An early introduction to architecture and design helps develop visual and spatial skills, and gets children to interact with their environment. When children are exposed to concepts like designing an 'experience', for example, like walking through an airport or using an ATM, they are no longer living life passively (Kumar, 2018).

As the new emerging techniques replace the cumbersome and time-consuming manual procedures, the older modes of creative pursuits are being done away with (NCERT, 2010). Information and Communication Technology (ICT), exhibitions of arts and design, animation films, computer based sets and special stage effects, fusion of music and dance in events like puppetry are already being accepted as education through arts (NCERT, 2010). Such methods must be embraced to at once achieve appreciation for traditional art forms and understand how public memory is shaped, and develop a more holistic outlook to the process of education itself.

\section{REFERENCES}

Agrawal, A., (Feb 26 2020), 'A more democratic art? How the digital sphere is shaping culture and counter-culture in India', Firstpost, Retrieved from: https://www.firstpost.com/living/a-more-democratic-art-how-the-digital-sphere-isshaping-culture-and-counter-culture-in-india-8049081.html?

Beach, M, (2002), Steps to Water: The Ancient Stepwells of India, Princeton Architectural Press

Buncomble, A., (2011), 'MF Husain: Indian artist who spent his last five years in self-imposed exile after death threats from Hindu nationalists', The Independent, https://www.independent.co.uk/news/obituaries/mf-husain-indian-artist-who-spent-hislast-five-years-in-self-imposed-exile-after-death-threats-from-2299330.html

Camlin, (November 22 2013), 'The Origin and Evolution of Indian Art', Retrieved from: https://www.kokuyocamlin.com/blog/the-origin-and-evolution-of-indian-art.html

Dikshit, K.R., and Schwartzberg, J., (2020), 'Indian Architecture', Encyclopædia Britannica, https://www.britannica.com/place/India

Dutta, A., (2018), 'The Changing Culture of Architecture in Modern India', Archinect Features, Retrieved from: https://archinect.com/features/article/150048645/the-changing-cultureof-architecture-in-modern-india

Gast, K., (2007), Modern Traditions: Contemporary Architecture in India, Birkhäuser 
Harle, J.C., The Art and Architecture of the Indian Subcontinent, 2nd edn. 1994, Yale University Press Pelican History of Art

Kumar, S., (January 19 2018), 'Why Art needs to stay in class', The Hindu, Retrieved from: https://www.thehindu.com/education/schools/why-art-needs-to-stay-inclass/article22471482.ece

NCERT, Dept. of Education in Arts \& Aesthetics, (2010), 'Art Education in India, Country Report', Ministry of Human Resource Development

Singh, D., (2018), 'Indian art, artists, and its historical perspective', International Journal of Academic Research and Development, Vol.3, Issue 6

Tadgell, Christopher (1990). The history of architecture in India: from the dawn of civilization to the end of the Raj. London: Architecture Design and Technology Press

Thapar, Bindia (2004). Introduction to Indian Architecture. Singapore: Periplus Editions

UNESCO, (2018), "Victorian Gothic and Art Deco Ensembles of Mumbai".

UNESCO, (n.d), 'Qutb Minar and its Monuments, Delhi', Retrieved from: https://whc.unesco.org/en/list/233 